\title{
PROTECTION

\section{THE CASE STUDY OF VILLA BEATRICE D'ESTE: MANAGEMENT PLANNING OF A MULTI-LAYERED SITE WITH MEDIEVAL RUINS IN THE VENETO REGION, ITALY}

\section{GAMBA Valentina ${ }^{1}$ CALÒ Sergio ${ }^{2}$ MALÉ Maurizio ${ }^{3}$ MORETTO Enzo ${ }^{4}$}

${ }^{1}$ Valentina Gamba, Venetian Cluster https://orcid.org/0000-0001-9777-2055

2 Sergio Calò, Venetian Cluster

${ }^{3}$ Maurizio Malé, Venetian Cluster

${ }^{4}$ Enzo Moretto, Butterfly Arc Ltd. https://orcid.org/0000-0002-7985-1005

ABSTRACT: Villa Beatrice d'Este is a 17th century Venetian Villa in the Veneto Region, Italy, located within the area of the Euganean Hills Regional Park. The villa was built to replace a previous 13th century Medieval Monastery, whose structure was integrated in the villa. Remains of the Medieval structures are still visible today. The monumental complex constitutes an example of a multi-layered site with continuous life from Medieval times up to the present days. For this reason, the site was selected as a case study by the EU-funded project RUINS ${ }^{1}$, in view of proposing a management plan to protect and valorise its complex heritage, as an example of heritage site with Medieval ruins in Europe.

KEY WORDS: Medieval heritage, ruins, Venetian Villas, sustainability, valorisation, protection

1 RUINS, Sustainable re-use, preservation and modern management of historical ruins in Central Europe - elaboration of integrated model and guidelines based on the synthesis of the best European experiences. A project funded by the EU through the Interreg Central Europe Programme. 


\section{Introduction}

Villa Beatrice d'Este is a heritage site located within the Regional Park of the Euganean Hills in the Veneto Region, in the north-east of Italy. The site comprehends a Venetian Villa dating back to 1675 , built on the structures of a previous 13 th century Medieval monastery. The monumental complex is located on top of a 280-meters-high hill with a flat and elongated plateau, the Mount Gemola, in a strategic position within the Euganean Hills area. The villa was listed by the Italian Ministry of Culture as protected heritage site in 1971. The site of Villa Beatrice is today public property of the Province of Padua and its ground floor hosts the premises of the Provincial Museum of the Flora and Fauna of the Euganean Hills.

The villa was selected by the EU-funded project RUINS as a case study to investigate how Medieval ruined heritage can be sustainably valorised and protected to make a strong contribution to local development. The present article presents the Management Plan that was elaborated with this purpose, giving an overview of the steps undertaken and of the results achieved. The Management Plan was organized according to the following structure: the first part provides a comprehensive diagnosis of the site, with a thorough description of its features and values; the second part tackles the protection and management of the site; the third part presents an analysis of the possible productive activities that could be introduced in the site to better valorise it in the future.

\section{Diagnosis of the site}

History and functions of the site

According to medieval archival sources attesting the presence of a fortress on top of the Mount Gemola, the history of the heritage site of Villa Beatrice d'Este could date back at least to the 10 th century ${ }^{2,3}$, although the surrounding area shows signs of earlier occupation ${ }^{4,5}$. Most likely, such fortified structure was supplanted by a male monastery between the end of the 12th and

\footnotetext{
2 Quarena M., Castelli, monasteri e paesaggi agrari tra Baone, Calaone e Valle San Giorgio, [in:] Brogiolo, 2017, p. 116; Quarena M., Insediamenti e paesaggi agrari storici di Baone, Calaone e Valle San Giorgio, Tesi di Laurea, Università degli Studi di Padova, 2014, p. 156; Cogo B., Beata Beatrice d'Este. 1191-1226. Venerazione e memoria storica. Terra d'Este. Rivista di storia e cultura, Anno XXVII, n. 53, 262 pp., Este: Gabinetto di Lettura Este, 2017, p. 51; Settia A. A., Castelli Euganei, [in:] Selmin, 2005, p. 113.

3 A Çemole de la Roca (Fortress of the Gemola) is mentioned in the year 1184, but the term "roca" could refer to an older structure.

4 Cogo B., Beata Beatrice d'Este. 1191-1226. Venerazione e memoria storica. Terra d'Este. Rivista di storia e cultura, Anno XXVII, n. 53, 262 pp., Este: Gabinetto di Lettura Este, 2017, p. 51; Quarena M., Insediamenti e paesaggi agrari storici di Baone, Calaone e Valle San Giorgio, Tesi di Laurea, Università degli Studi di Padova, 2014, p. 155.

5 A Roman rural structure found on the eastern slope of the Gemola hill, and other pre-Roman, Roman and Lombard material evidences where found in nearby areas.
} 
the beginning of the 13th century $y^{6,7}$.

Certainly, in the year 1221, the male monastery was replaced by a new female monastery, founded by the Blessed Beatrice of Este with the support of the Church Establishment ${ }^{8}$. Beatrice of Este was the daughter of Azzo VI, marquis of Este, one of the most powerful and influential leaders of the 13th century political scene in Europe. Beatrice founded a new religious community, which continued to live in the Mount Gemola also after her death (1226), most probably embracing the Benedictine rule. While it was the siege of a monastery, the site was organized to host the life of its community, thus including spiritual and productive areas, according to the Benedictine tradition. According to sources and archaeological evidence, the monastery included surrounding walls, a church, a dormitory, a refectory, a cloister (probably first with one-sided portico and later with a four-sided portico), a well with a cistern for collecting rainwater, a grangia (productive/ agricultural part), a cemetery.

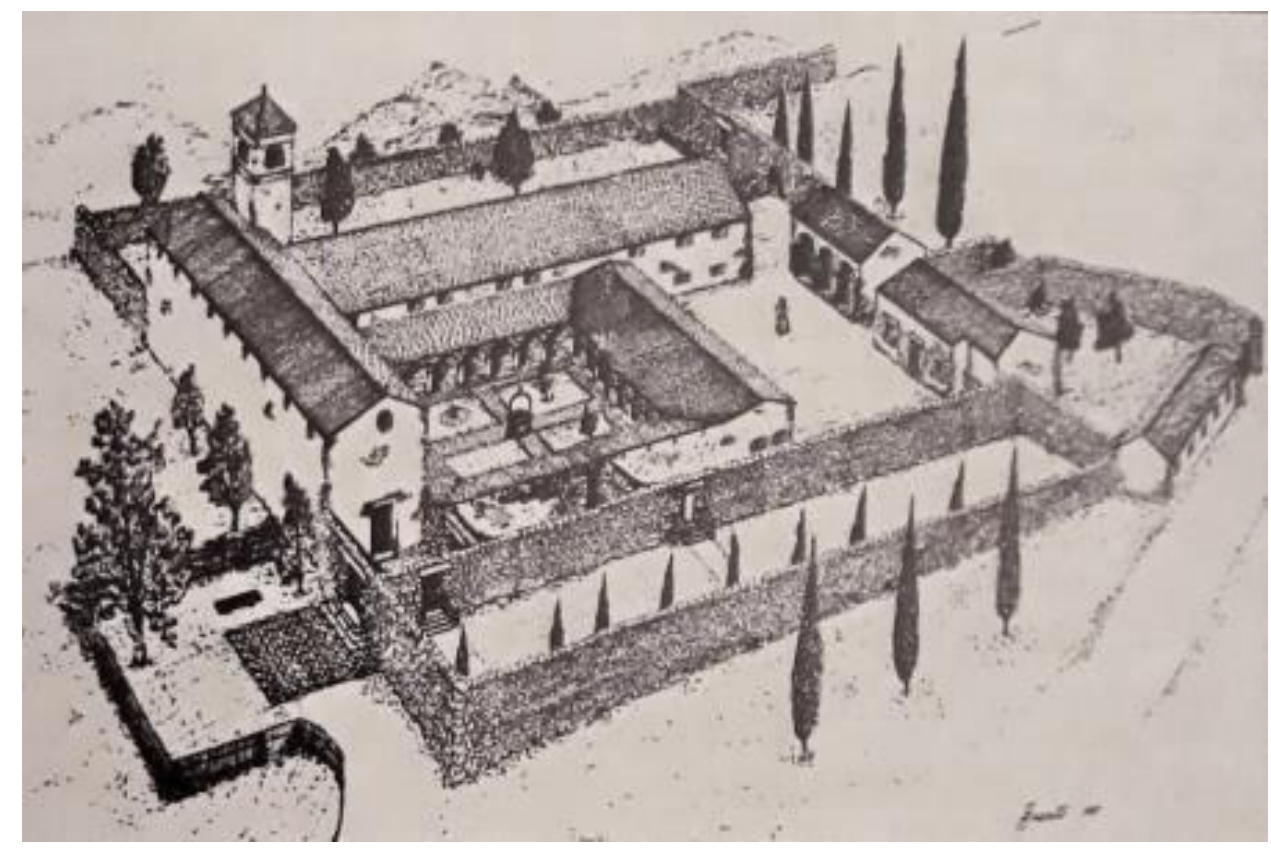

Fig.1 Possible reconstruction of the Gemola monastery in the 16th century (Cogo B., Beata Beatrice d'Este. 1191-1226. Venerazione e memoria storica. Terra d'Este. Rivista di storia e cultura, Anno XXVII, n. 53, 262 pp., Este: Gabinetto di Lettura Este, 2017, p. 69)

6 Cogo B., Beata Beatrice d'Este. 1191-1226. Venerazione e memoria storica. Terra d'Este. Rivista di storia e cultura, Anno XXVII, n. 53, 262 pp., Este: Gabinetto di Lettura Este, 2017, pp. 52-54; Polizzi C. F., Alle origini del monastero di S. Giovanni Battista del Gemola, [in:] Atti e memorie dell'Accademia Patavina di Scienze, Lettere ed Arti, 103, III, 1992.

7 A first mention of a male monastery is in a testament dated to the year 1215. In the same year, the foundation of a church dedicated to Saint John the Baptist is attested by another archival source, confirming the presence of a male monastery on the Mount Gemola by the year 1215 .

8 Cogo B., Beata Beatrice d'Este. 1191-1226. Venerazione e memoria storica. Terra d'Este. Rivista di storia e cultura, Anno XXVII, n. 53, 262 pp., Este: Gabinetto di Lettura Este, 2017, pp. 53-54. 
The life of the Gemola monastery continued until the second half of the 16th century, when the Diocese of Padua decided to transfer its community to Padua and sell the property. Following some transfers of ownership, around the year 1657 the monastery was transformed into a villa by the initiative of a Venetian goldsmith merchant, Francesco Roberti'. However, the shaping of the villa as it can be seen today must have taken place gradually, with some important interventions during the 18th century by the Bregolini family ${ }^{10}$. The architecture of the Venetian Villa used and adapted the structure of the previous monastery, maintaining its hierarchical organisation, for example by positioning the central hall in correspondence of the old refectory. As Venetian Villa, the site continued the rural productive functions of the monastery and became a prestigious residence with housing and representative functions. At the beginning of the 20th century, a rural building (barchessa) was added to the villa in support of its agricultural activities.

The villa became a public property in 1972, following its listing as national cultural heritage in 1971. At that point, the villa stopped its direct productive activities (the agricultural properties around the villa were rented) and stopped to be inhabited by its owners ${ }^{11}$. Following a thorough restoration during the 1970s, which included onsite archaeological investigations, the site became the premises of the Museum of the Flora and Fauna of the Euganean Hills. The functions shifted then to educational and to services (mainly the provision of a venue for events).

\section{Context}

Villa Beatrice d'Este is located on top of Mount Gemola, (281 $\mathrm{m}$ a.s.l.), a relief in the southern area of the Euganean Hills Regional Park, within the territory of what is today the Municipality of Baone. It is located in a strategic position, in visual contact with other Euganean reliefs such as Mounts Rua and Venda.

Thanks to their peculiar geomorphology $y^{12}$ and the central position in the Po valley system, the Euganean Hills have been continuously inhabited since ancient times ${ }^{13,14}$. The Euganean landscape is thus the result of centuries of interaction between man and the environment.

During the Medieval Ages, and particularly from the 10th to the 12th century, several small settlements developed in the area, such as fortified castles and monasteries, which were usually located in raised positions and near fresh water sources (as Villa Beatrice). This network of settlements ensured control of the territory, also through the organization of productive

\footnotetext{
9 As attested by an inscription that is still conserved at the site of Villa Beatrice.

10 Cogo B., Beata Beatrice d'Este. 1191-1226. Venerazione e memoria storica. Terra d'Este. Rivista di storia e cultura, Anno XXVII, n. 53, 262 pp., Este: Gabinetto di Lettura Este, 2017, pp. 200-205.

11 A caretaker has been living a northern part of the villa since.

12 Hilly reliefs intersected by valleys and plains, rich in springs, with good variety of vegetal and animal species.

13 Zanovello P., Le prime tappe della storia: tra Euganei, Veneti e Romani, [in:] Selmin, 2005.

14 The first signs of anthropic settlements in area date back to the lower and middle Palaeolithic. The first proto-urban (and then urban) settlements, Padua and Este, were established by the ancient Veneti civilization starting from the first millennium BC. During the Roman period, Padua controlled the eastern Euganean area including the thermal springs, and Este controlled the south-western areas, which were widely occupied by a dense network of rural settlements, up to the Berici hills.
} 
activities, such as agriculture, and the regimentation of marshy waters in the lower plain areas ${ }^{15}$. This pattern continued during the 16th century with the spread of Venetian Villas, which in fact were often replacing previous medieval castles or monasteries ${ }^{16}$.

Based on these elements, a common trend in the settlement system of the Euganean Hills can be highlighted: the area was never interested by large urban settlements, which were rather located at the borders of the area (Monselice and Este); it was controlled and managed through a capillary network of small settlements organized around attractive poles (castles and monasteries first, and Venetian Villas later). This pattern has continued up to today.

Agriculture has been one of the main economic activities, which has significantly contributed to shape the Euganean landscape. Agriculture was intertwined with the development of settlements and the control of the territory, as it was linked to the regimentation of waters and to the overall organization of lands. Since ancient times and up to today, the cultivation of vineyards has been the most widespread and valuable agricultural activity, as it has allowed to take advantage of the hilly slopes and to benefit from the rich variety of Euganean soils.

Hence, the overall Euganean Hills area has a rich natural and cultural heritage. The latter includes archaeological areas, Medieval castles, and monasteries, and several Venetian Villas. Many museums were established to reflect and valorise such heritage, including private and public.

The Euganean Hills area is part of the Tourism Destination "Thermae and Euganean Hills", which includes also the prestigious thermal areas of Abano and Montegrotto Terme. According to recent analysis (OGD 2018) and also to direct observation following the COVID-19 pandemics, the tourism market shows and increasing attention towards the territory of the Euganean Hills, which represents a newer market, due to the kind of offer: outside/ open air activities, slow tourism, eno gastronomic tourism.

\section{Formal description of the site and state of conservation}

Villa Beatrice covers a flat area of about one hectare on top of Mount Gemola. The complex consists of the main body of the villa, which extends longitudinally in a north-east south-west direction overlooking a courtyard, and a rural building (barchessa), on the north side of the courtyard.

The villa is connected to two gardens placed at lower levels (following the slopes of the hill) on its western and eastern sides (corresponding to the ancient cemetery and to the ancient brolo of the Medieval monastery respectively). A large walled meadow area is located to the south of the complex. The villa can be accessed from a monumental portal leading to the medieval paved ramp climbing up to the northern and southern entrances of the courtyard. In the outside area, preserved imposing containment walls of the medieval monastery can be observed below and around the western and eastern gardens.

15 Brogiolo G. P., Paesaggi storici dei Colli Euganei e della pianura padovana tra età romana e medioevo, [in:] Brogiolo, 2017; Settia A. A., Castelli Euganei, [in:] Selmin, 2005; Rigon A., Pievi, monasteri, eremi, [in:] Selmin, 2005.

16 Monti G., Padova: città e campagne, [in:] Zucchello (XV-XIX), 2001. 
24 Valentina Gamba, Sergio Calò, Maurizio Malé, Enzo Moretto

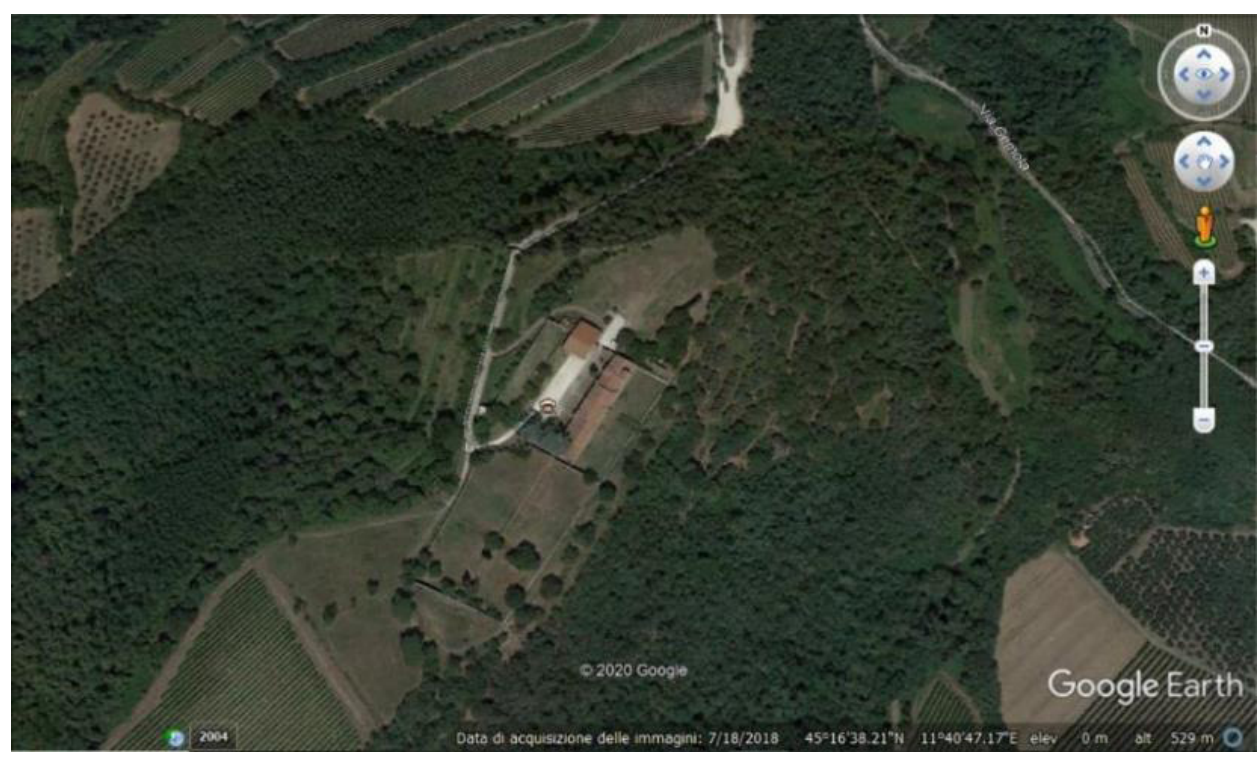

Fig. 2 Aerial view of the monumental complex of Villa Beatrice (๔ Google 2020)

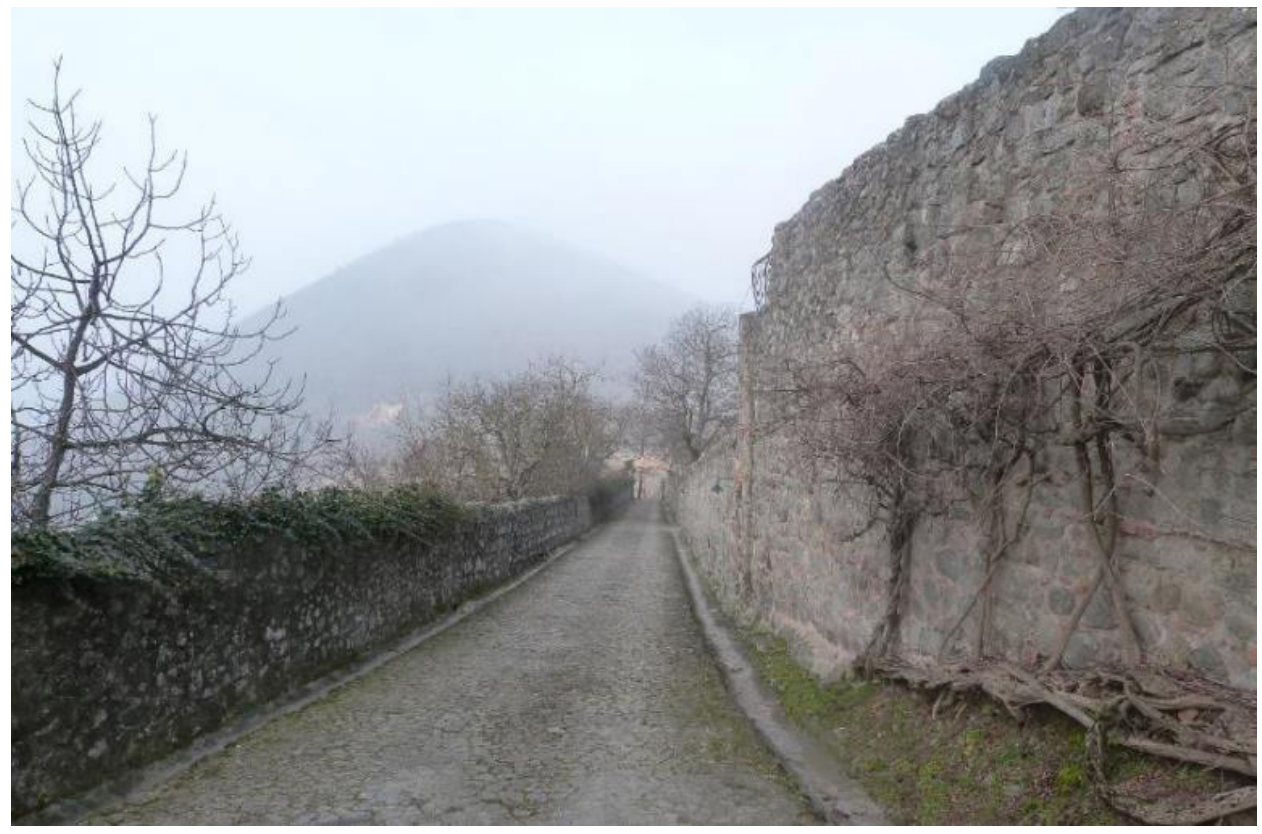

Fig. 3 View of the access ramp from above, showing the medieval walls and the portal at the bottom 




Fig. 4 Detail of the western garden of Villa Beatrice, corresponding to the ancient cemetery of the medieval monastery. The garden, here photographed in its northern part, covers a longitudinal zone that flanks the courtyard and is located at a lower level

The courtyard is located between the villa and its western garden (old cemetery). It is delimited to the south by a ruined medieval standing wall with barred windows that was interpreted as a remain of the ancient monastery stables; to the north, it is delimited by the rural barchessa and an entrance stone and brick wall, which was identified as the ruins of the medieval monastery church. Under the portico of the barchessa are some epigraphs testifying to the history of the complex ${ }^{17}$. Below its floor, remains of the foundations of the ancient medieval church and some burials of that time were highlighted during the excavations of the 1970s and 1980s and are still visible. In the courtyard are two wells: the northern one dating back to 1264 and evidence of the ancient monastery; the southern one more recent, dating back to the time of construction of the villa. Between the eastern and western garden, to the south of the main villa, are the ruins of what has been interpreted by archaeologists at the ancient dovecot.

17 The 1657 inscription that reports the restoration works of the church carried out by Francesco Roberti; the inscription of the monastery restoration works commissioned by the abbess Maddalena Zacarota in 1510 and the coat of arms of the same abbess. 


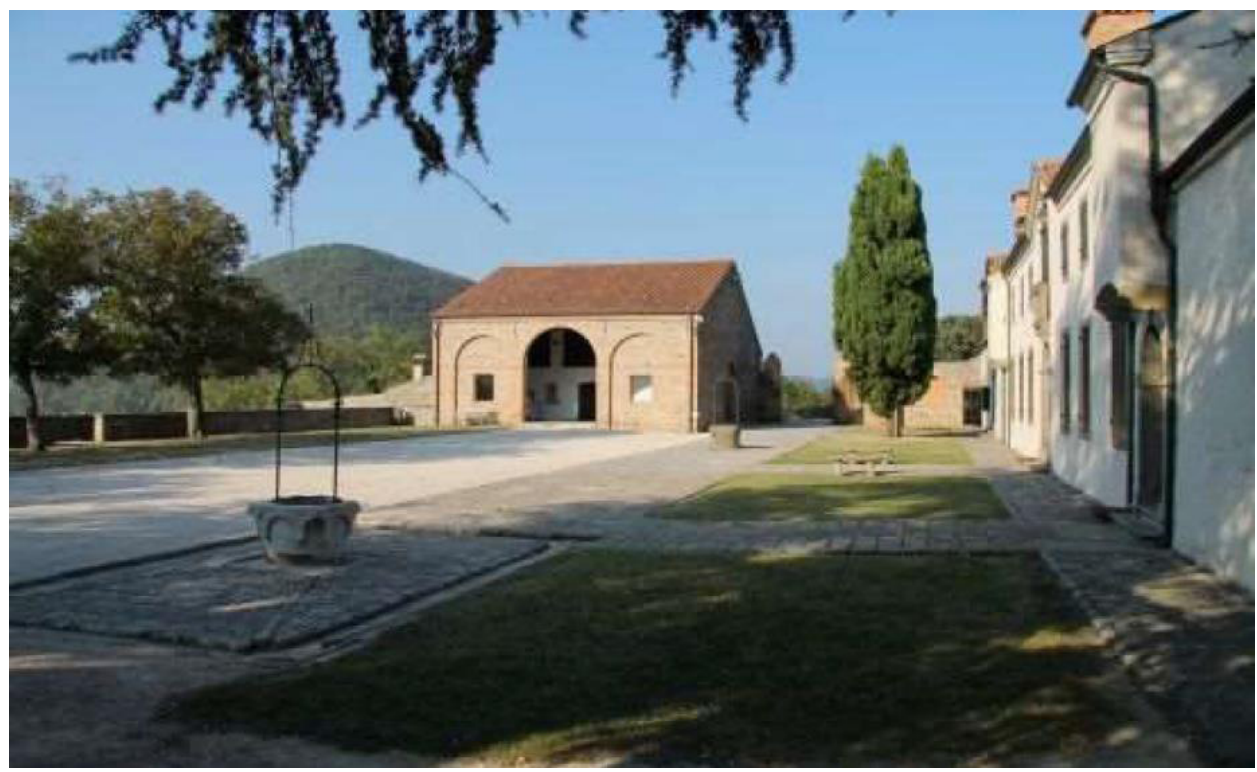

Fig. 5 The courtyard view from south with the modern barchessa and the two wells

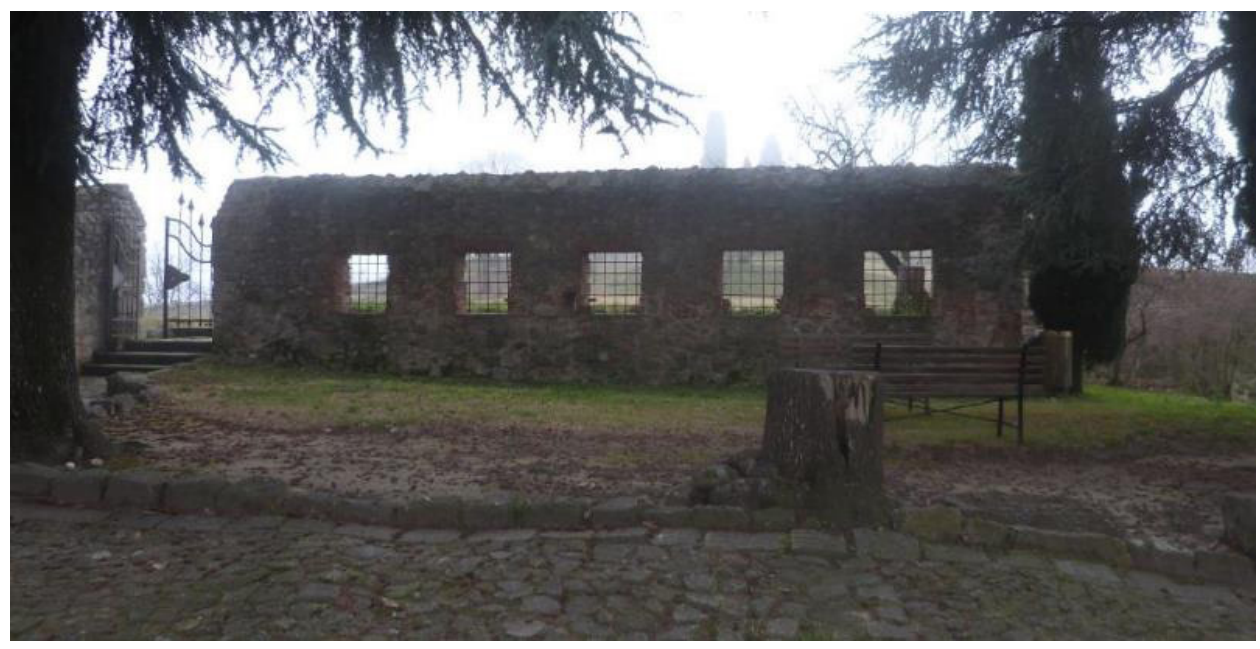

Fig. 6 Remains of the wall of a medieval structure on the southern side of the courtyard, which were identified as part of the medieval monastery stables 


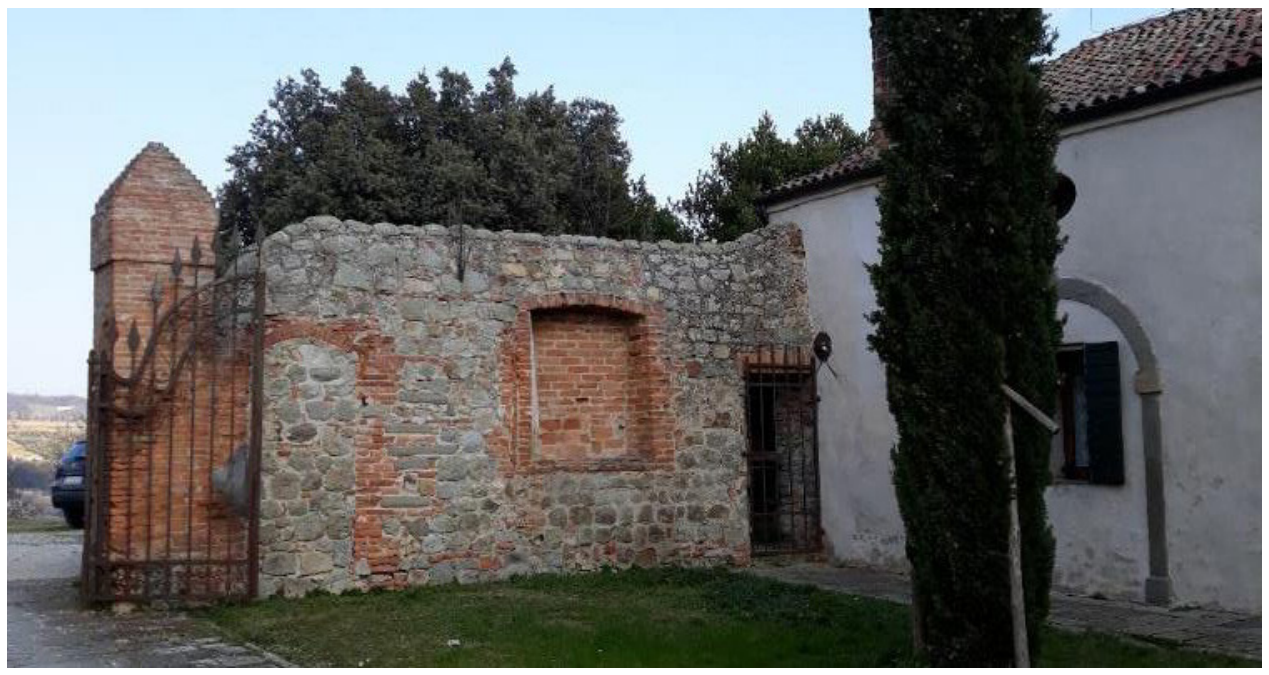

Fig. 7 Detail of the northern wall of the monumental complex, which has been identified as the northern wall of the ancient medieval church of the monastery. In the wall, a niche and a walled door are visible

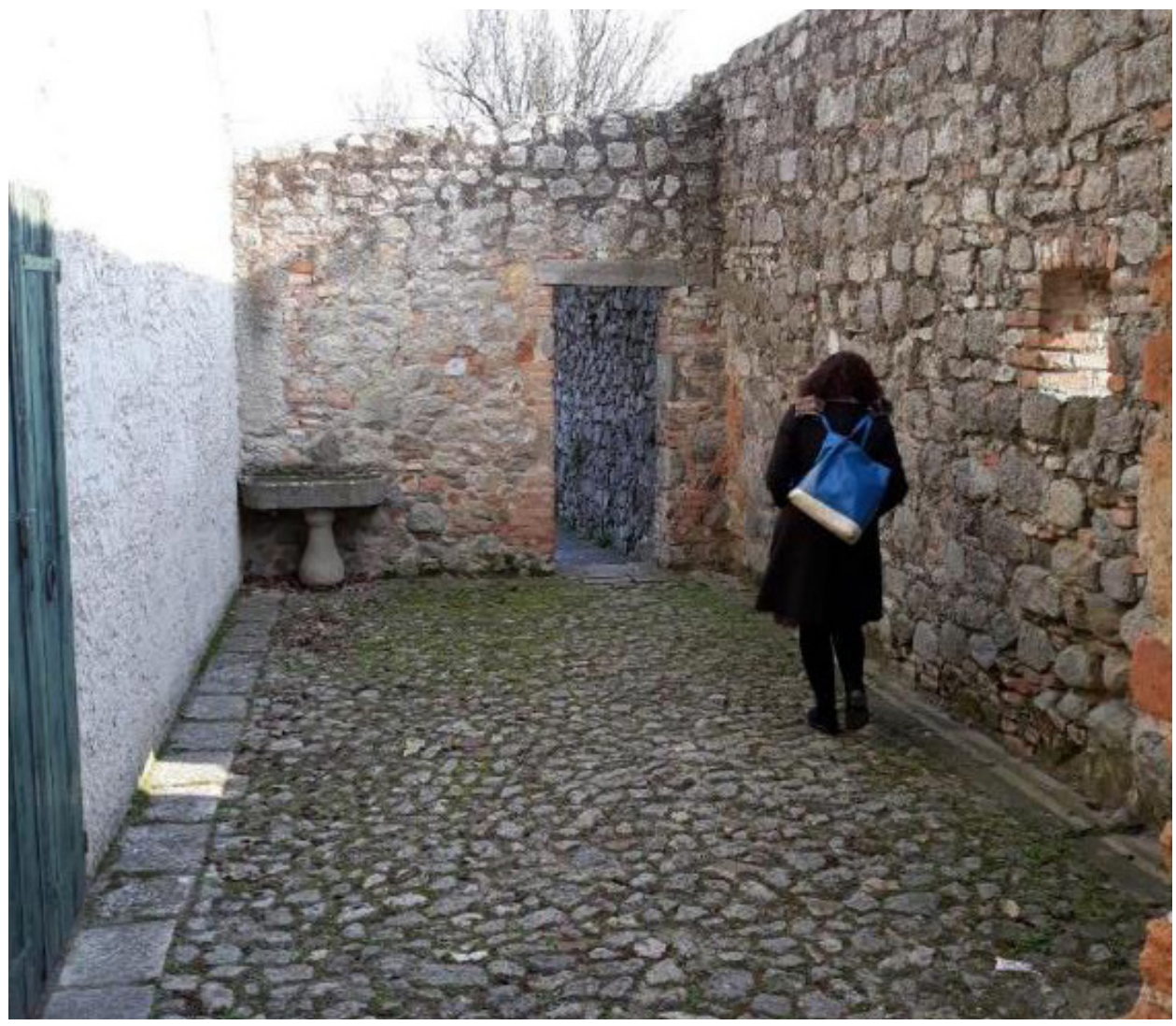

Fig. 8 Open space surrounded by medieval walls on the southern side of the villa, connecting the courtyard to the eastern garden or brolo. The area has been interpreted as the remains of the ancient monastery dovecote attested by written sources 
The villa itself is the result of several interventions that adapted the remains of the medieval monastery. The main central villa is a two-storey building with triangular tympanum. It was built on the traditional tripartite plan of the Venetian noble residences, with a central hall that extends over the entire depth of the building, and four symmetric side rooms. The rooms are covered with Venetian floors. The central hall has a double height, with a precious 18th-century wooden balustrade delimiting a balcony, which was used for musicians during events. Although the plan is typical of Venetian residences, the structure was adapted to the old structures of the monastery, as shown by some material evidences of the medieval monastery that are still visible: wall niches, probably corresponding to the former entrances of the ancient refectory; a stone with a Greek inscription reused in the construction of the same wall; portions of terracotta flooring visible under the floor level; two fireplaces and a hand basin made of carved stone.

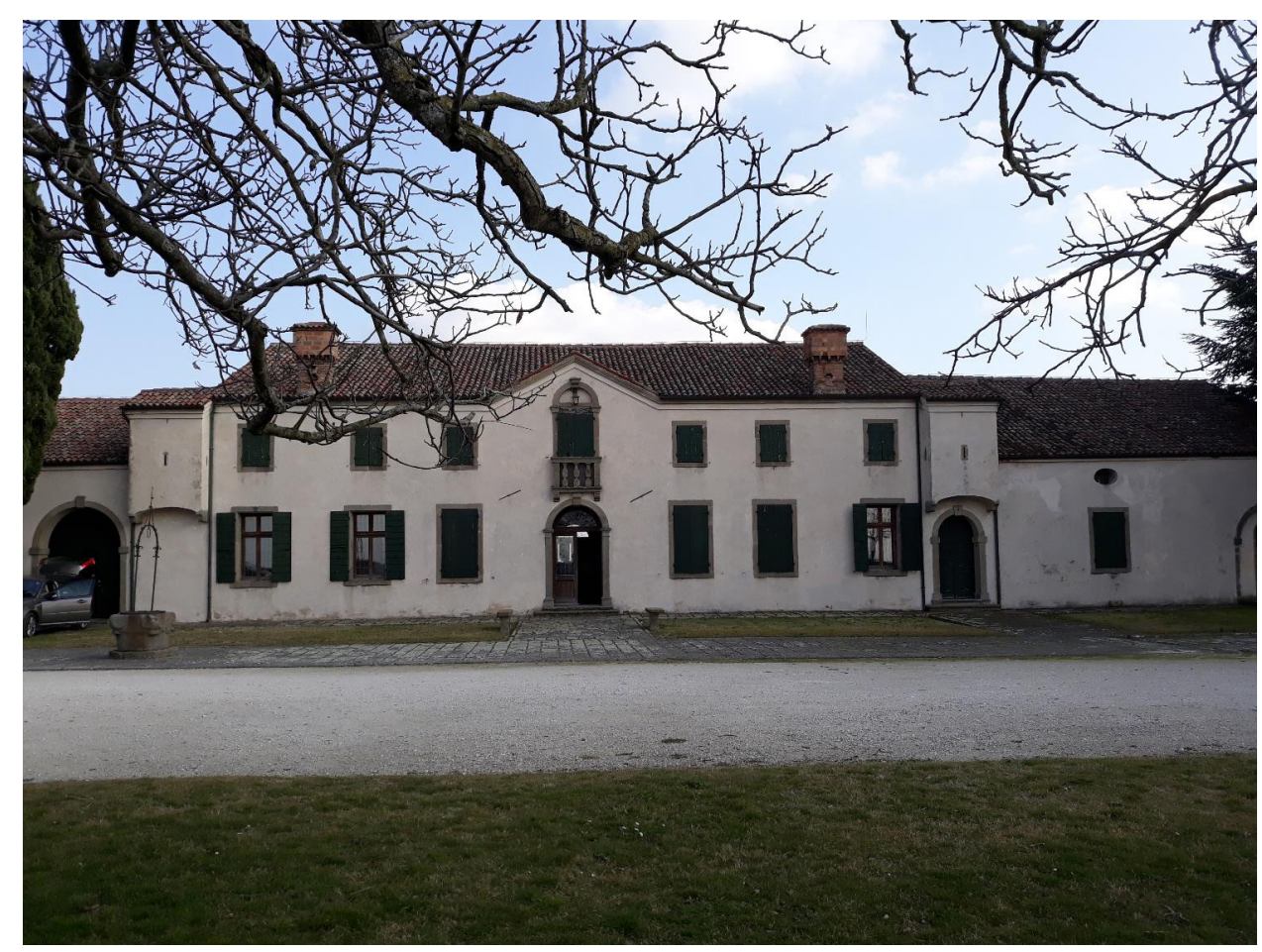

Fig. 9 Western prospect of Villa Beatrice d'Este, facing on the courtyard 


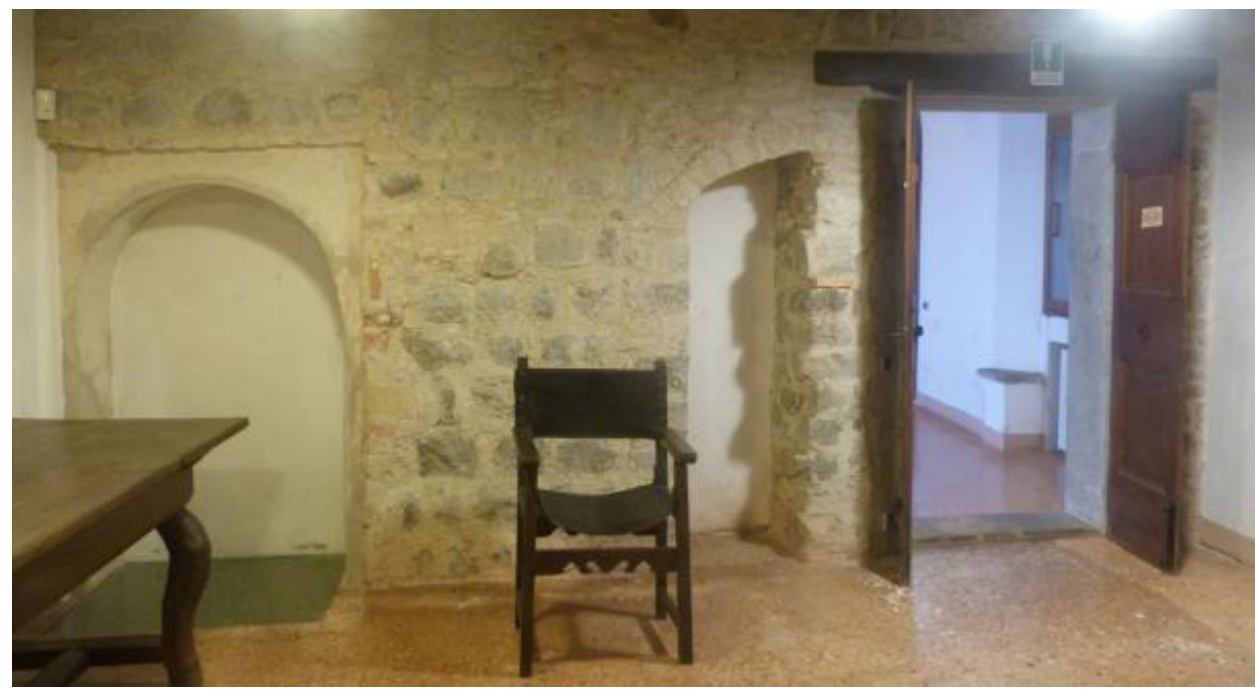

Fig. 10 Northern wall of Room B, where the remains of the ancient entrances to the medieval monastery refectory are visible. Below the floor level, it is a portion of the ancient medieval floor (on the left)

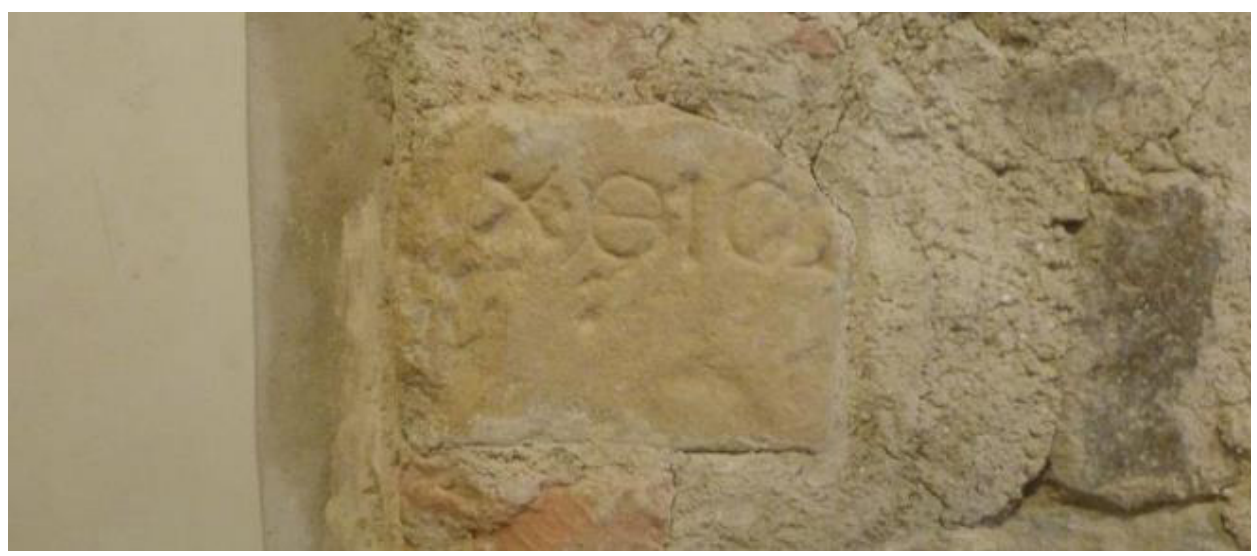

Fig. 11 Detail of a stone with inscription reused in the northern wall of Room B

To the north of the main villa, is a spacious room with a modern wooden mezzanine, the socalled "carriage room". The carriage room connects the villa with the oratory of the manor house dedicated to St. John the Baptist. The oratory has a single nave with rectangular shape, covered by a wooden ceiling. On its floor are three underground tombs of the families that inhabited the villa ${ }^{18}$. Above the door of the oratory there is a painted Latin inscription that attests to the works of 1708 by Count Bartolomeo Bregolini and reports that the oratory is located where the ark of

18 That of Count Pietro Bregolini, son of Bartolomeo, who died young in 1746 at the age of 33, as stated in the epigraph; that of his son Bartolomeo, who died of just nine months in 1733; the tomb of Countess Beatrice Prosdocimi Bregolini de Panico, who died in 1802. 
the Blessed Beatrice was preserved for 300 years ${ }^{19}$.

To south of the main villa are some rooms that probably correspond to the old kitchen and cellar. Now they host the Museum of the Flora and Fauna of the Euganean Hills and a small shop and café area. The upper floor of the villa (noble floor) follows the same plan of the ground floor. The overall state of conservation of the villa is good, both in its internal and external parts. The structure would need consolidation of the stone walls and a maintenance of the surfaces (old plaster), respecting the original materials, and of the external areas, to avoid propagation of vegetation that could damage the walls. Some medieval structures have been incorporated into the villa, whereas others are in a state of ruins in the outside area, showing a good state of conservation. Containment walls of medieval origin are in a good state of conservation and are still in use with the same containment function.

\section{Connections}

Villa Beatrice d'Este is not connected to the public transport network. The closest train stations are those of Battaglia Terme, Monselice and Este but there is no public connection from the train stations to the site. Hence the site is reachable by car only, or, alternatively, on foot, by bicycle or horse.

\section{Site values and Integrity \& Authenticity}

Based on the above analysis, values defining the cultural significance of the site were proposed. Each identified value can be linked to specific attributes, which need to be safeguarded and valorised in the Management Plan. Then, integrity and authenticity of the site, with reference to identified values, were analysed, as shown in Table 1.

Historic value: Villa Beatrice d'Este is an example of 17 th-century Venetian Villa, testimony to the development of villas in the Veneto Region, as part of the historical, social, economic and cultural context of the Republic of Venice during the 1500s and 1600s. Within the framework of the Venetian Villas in the Province of Padua ${ }^{20}$, Villa Beatrice is among those buildings that replaced previous religious settlements and therefore represents an example of adaptation and continuity of use of pre-existing religious structures during the development of Venetian Villas in the Euganean Hills area. On top of this, the villa is strictly linked to the historical importance of the medieval monastery that preceded it, a monastery that was founded in 1221 by the Blessed Beatrice of the Este family, one of the most influential families in north of Italy at that time. The foundation of a monastery by a young noblewoman in search of spiritual life is part of the phenomenon of the pauperistic movements of Italy in the early 13th century, which largely involved the aristocratic female world (the experiences of Francis of Assisi and Saint Claire are contemporary). Furthermore, the patronage of the Este family over the monastery testifies to the political balance of that specific historical context.

19 Cogo B., Beata Beatrice d'Este. 1191-1226. Venerazione e memoria storica. Terra d'Este. Rivista di storia e cultura, Anno XXVII, n. 53, 262 pp., Este: Gabinetto di Lettura Este, 2017, p. 209 and following.

20 Zucchello N., Ville venete: la Provincia di Padova, IRVV, Marsilio, 2001. 


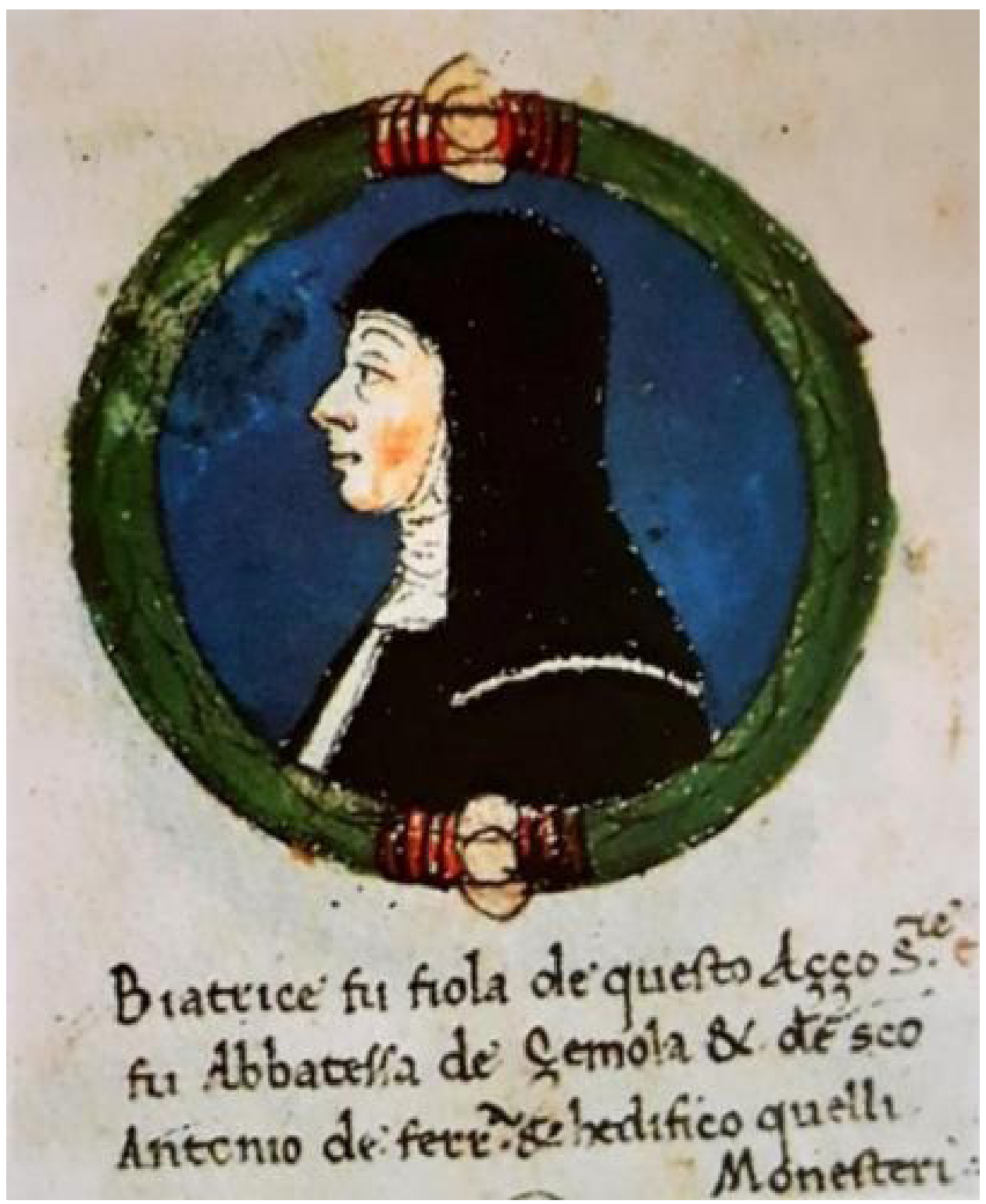

Fig. 12 the Blessed Beatrice of Este from the Iconografia Estense (Cogo B., Beata Beatrice d'Este. 1191-1226. Venerazione e memoria storica. Terra d'Este. Rivista di storia e cultura, Anno XXVII, n. 53, 262 pp., Este: Gabinetto di Lettura Este, 2017, p. 95).

Historic landscape values: Villa Beatrice is located on the top of Mount Gemola, with a $360^{\circ}$ view over the surrounding landscape and in visual connection with other Euganean reliefs. The position in the context of the Euganean Hills Park and the view over the landscape are unique features of the villa compared to other sites of cultural interest in the area. The Mount Gemola has large woods on its sides, including chestnut woods, flanked by the cultivation of vine, testifying to a centuries-old interaction between man and the environment. The location of the 
site is ideal in the context of the hills: raised above the plain, near water sources, surrounded by woods and cultivable areas, easily defensible. The site is thus testimony of a typical medieval settlement, which contributed to shaping the surrounding landscape.

Architectural value: the villa is an example of the 17th-century Venetian Villas architecture in the Province of Padua. The villa is sober and simple. It has a typical tripartite plan with a central hall, with a beautiful wooden balcony and a coffered ceiling. It differs from other contemporary examples for being built on the ruins of a previous medieval monastery, reusing its main structures (some of which were highlighted thanks to archaeological excavations and restoration). The massive enclosure and containment walls of the ancient monastery are still preserved and strongly qualify the external look of the monumental complex. There are other examples of villas built to replace ancient monasteries in the Euganean Hills area, but, unlike these examples, Villa Beatrice retains a more accentuated sobriety, and preserves more extensive parts of the original medieval architecture.

Archaeological value: thanks to the archaeological investigations conducted in the 1970s and 1980s, remains of the ancient medieval monastery are visible in situ. Therefore, the villa is a material testimony of an ancient medieval monastery, with an important value for reconstructing the early medieval history of the Euganean Hills and providing information that otherwise would not be available solely through written sources. The archaeological value is also potential, as more investigations in the area around the villa and further analysis of the wall stratigraphy would provide even more information on the history of the site and on its relationship with the agricultural and production context of the Euganean Hills.

Symbolic, social, and religious values: Beatrice of Este founded the monastery on which Villa Beatrice was built. The memory of the Blessed Beatrice remains not only in the name of the monumental complex, but also in a series of material and historical memories that link the site to the surrounding area. The oratory of the villa, dedicated to Saint John the Baptist, maintained a direct link with the history and figure of Beatrice over the centuries: it is dedicated to Saint John the Baptist, as the monastery founded by the Blessed, and it stands right on the site of the ancient sacristy where the body of the Blessed had been preserved after her death and before it was transported to Padua. The memory of the Blessed Beatrice and her story have been transmitted in the religious and popular culture of the Province of Padua and the Euganean Hills up to the present day. This tradition led to the official declaration of the cult of the Blessed during the 18th century. The figure of the Blessed Beatrice keeps a strong religious significance for the local communities and she is still worshipped in the Euganean Hills area: her body is now preserved in the Cathedral of Este, where she is also patron of the city. The site maintains a strong spiritual value, where visitors can find peace and tranquillity.

Educational value: with the introduction of the Museum of the Flora and Fauna of the Euganean Hills of the Province of Padua, the site of Villa Beatrice acquired an added educational value, which could be further integrated with the history of the villa, with focus on the interaction between man and the environment over the centuries in the Euganean Hills area (for example, by elaborating on the use of plants by monks, or on old agriculture and productive activities and practices). 
Authenticity and integrity: the complex of the villa is in a good state of conservation and is intact in all its parts. The medieval monastery was incorporated into the villa, and therefore is part of it. Medieval ruins visible in situ are preserved but could be better valorised to allow visitors to fully understand the values of the site. Despite having changed functions over the centuries, the site maintained a strong sense of spirituality and meditation. The architecture is original in its elements and maintained the austere aspect of the previous religious building, with a parsimonious use of decorative elements. Visitors would still find in Villa Beatrice a place of peace and tranquillity, surrounded by the nature of the Euganean Hills.

\begin{tabular}{|c|c|c|c|}
\hline Site values & Attributes & Integrity & Authenticity \\
\hline \multirow{4}{*}{ Historic value } & $\begin{array}{l}\text { Overall monumental } \\
\text { complex of the villa }\end{array}$ & Yes & $\begin{array}{l}\text { Yes. The only modern } \\
\text { addition to the site is } \\
\text { the 20th century rural } \\
\text { barchessa, which was } \\
\text { built where the ancient } \\
\text { church once stood, but } \\
\text { that had been levelled } \\
\text { since two centuries } \\
\text { when the barchessa was } \\
\text { built }\end{array}$ \\
\hline & $\begin{array}{l}\text { Remains of the ancient } \\
\text { monastery of the } \\
\text { Blessed Beatrice: walls, } \\
\text { and other structures }\end{array}$ & $\begin{array}{l}\text { Yes. Some are } \\
\text { integrated into the } \\
\text { villa. }\end{array}$ & Yes \\
\hline & $\begin{array}{l}\text { Inscriptions attesting to } \\
\text { the history of the villa } \\
\text { preserved onsite }\end{array}$ & Yes & Yes \\
\hline & $\begin{array}{l}\text { Memories and sources } \\
\text { attesting to the history } \\
\text { of the site }\end{array}$ & N/A & Yes \\
\hline \multirow{4}{*}{$\begin{array}{l}\text { Historic } \\
\text { landscape values }\end{array}$} & $\begin{array}{l}360^{\circ} \text { view around } \\
\text { the Euganean Hills } \\
\text { area with no visual } \\
\text { disturbance }\end{array}$ & Yes & N/A \\
\hline & $\begin{array}{l}\text { Chestnut woods on the } \\
\text { hilly slopes }\end{array}$ & Yes & N/A \\
\hline & $\begin{array}{l}\text { Water spring to the } \\
\text { south of the villa }\end{array}$ & Yes & N/A \\
\hline & $\begin{array}{l}\text { Vineyards in the } \\
\text { surrounding areas of } \\
\text { the villa }\end{array}$ & N/A & N/A \\
\hline
\end{tabular}




\begin{tabular}{|c|c|c|c|}
\hline \multirow{4}{*}{$\begin{array}{l}\text { Architectural } \\
\text { value }\end{array}$} & $\begin{array}{l}\text { Architectonic elements } \\
\text { of the villa }\end{array}$ & Yes & $\begin{array}{l}\text { Yes. The only modern } \\
\text { addition to the site is } \\
\text { the 20th century rural } \\
\text { barchessa, which was } \\
\text { built where the ancient } \\
\text { church once stood, but } \\
\text { that had been levelled } \\
\text { since two centuries } \\
\text { when the barchessa was } \\
\text { built }\end{array}$ \\
\hline & $\begin{array}{l}\text { Medieval structures } \\
\text { integrated within the } \\
\text { villa architecture }\end{array}$ & Yes & Yes \\
\hline & $\begin{array}{l}\text { Original floors of the } \\
\text { villa }\end{array}$ & $\begin{array}{l}\text { Yes, they are not } \\
\text { in perfect state of } \\
\text { conservation but minor } \\
\text { interventions would } \\
\text { be sufficient to restore } \\
\text { them }\end{array}$ & Yes \\
\hline & $\begin{array}{l}\text { Original wooden } \\
\text { ceilings and balcony }\end{array}$ & Yes & Yes \\
\hline \multirow{3}{*}{$\begin{array}{l}\text { Archaeological } \\
\text { value }\end{array}$} & $\begin{array}{l}\text { Standing medieval } \\
\text { walls in the outside } \\
\text { areas }\end{array}$ & Yes & Yes \\
\hline & $\begin{array}{l}\text { Excavated } \\
\text { archaeological remains } \\
\text { visible in situ }\end{array}$ & $\begin{array}{l}\text { Yes. The remains } \\
\text { would need to be } \\
\text { better valorised. Those } \\
\text { under floor level are } \\
\text { not clearly visible due } \\
\text { to humidity problems, } \\
\text { which however have } \\
\text { not hampered their } \\
\text { integrity }\end{array}$ & Yes \\
\hline & $\begin{array}{l}\text { Undisturbed areas } \\
\text { around the villa } \\
\text { with potential } \\
\text { archaeological } \\
\text { information }\end{array}$ & Yes & N/A \\
\hline \multirow{3}{*}{$\begin{array}{l}\text { Symbolic, social } \\
\text { and religious } \\
\text { values }\end{array}$} & $\begin{array}{l}\text { Oratory of Saint John } \\
\text { the Baptist }\end{array}$ & Yes & Yes \\
\hline & $\begin{array}{l}\text { Pictures, statues, and } \\
\text { inscriptions testifying } \\
\text { of the Blessed }\end{array}$ & Yes & Yes \\
\hline & Local worship & N/A & $\mathrm{N} / \mathrm{A}$ \\
\hline
\end{tabular}




\begin{tabular}{|c|c|c|c|}
\hline \multirow[b]{2}{*}{ Educational value } & $\begin{array}{l}\text { Overall monumental } \\
\text { complex of the villa }\end{array}$ & & \\
\hline & $\begin{array}{l}\text { Museum of the Flora } \\
\text { and Fauna of the } \\
\text { Euganean Hills }\end{array}$ & $\mathrm{N} / \mathrm{A}$ & N/A \\
\hline
\end{tabular}

Tab. 1 Site Values of Villa Beatrice, and assessment of integrity and authenticity.

\section{Protection and management of the site}

\section{Protection and management components}

Villa Beatrice is a public property, owned by the Province of Padua since 1989. The property includes the main body of the villa and a modern rustic annex (barchessa), and about 20 hectares of land.

The monumental complex of the villa was listed in 1971 pursuant to law 1089 of 1939 , then replaced by the legislative decree of 29 October 1999, n. 490, and by the Legislative Decree of 22 January 2004, n. 42, the Code of cultural and landscape heritage and subsequent additions. The competent authority is the Ministry of Cultural Heritage and Tourism, represented locally by the Superintendency of Archaeology, Fine Arts and Landscape for the metropolitan area of Venice and the provinces of Belluno, Padua and Treviso. According to the Code of Cultural Heritage, Villa Beatrice is a "monumental complex" (Art. 101,2) and also represents an "archaeological area" (Art. 101, 2, d). As such, the site is legally subject to protection obligations.

Following the restoration works carried out in the 1970s and 1980s, the complex was opened to the public, with the establishment of the Museum of the Flora and Fauna of the Euganean Hills in the southern wing of the villa. Since about ten years, the management and valorisation of the monumental complex is entrusted in concession to a third private party by the Province of Padua. The agricultural land around the villa is instead rented to a local farm and winery.

Based on this management system, the services currently offered at Villa Beatrice, and which are entirely managed by the third party through concession, mainly involve guided tours, didactic workshops and interactive itineraries, and the organization of events. The parts of the villa that are involved in such activities include the outside areas, including courtyard and both gardens, the museum and its shop/ café area, the carriage room (as service room for the catering services), and the central hall and side rooms at the ground floor of the villa. Currently, the spaces of the barchessa and the second floor of the villa are not managed and used.

Visitor flows

According to the data provided by the company that is currently managing the villa (Butterfly Arc Ltd.) the number of visitors to Villa Beatrice and its museum can be estimated to an average of 1,900 per year for the years 2015-2019, including school visits and events. To this figure, the non-paying visitors to the external areas should be added, which are estimated to be around 
20,000 per year. According to the same source, events organized in the past reached much higher numbers. Looking also at the tourist flows for the Destination "Thermae and Euganean Hills"21, data suggest that a more holistic management coupled with the organization of more events could lead to an increase in the number of visitors. In this regard, it is also interesting to analyse the tourism data at the regional level, where, in 2017 , more than $65 \%$ of the revenues for international leisure tourism were based on cultural reasons, primarily of a traditional type (61.8\% linked to the visit to the main cities of art), and also of an experience type (4.4\%). Furthermore, the cultural holidays registered the highest per capita expenditure on international tourism ${ }^{22}$. As regards the target groups, data are available only at destination and regional level, and show that the Italian market has a higher share at the level of the Euganean Hills ${ }^{23}$, whereas the foreign market is more important at the regional level, with a growing trend ${ }^{24}$.

\section{Stakeholder analysis}

Stakeholders with a link to the management of the heritage site of Villa Beatrice or potentially interested in its protection and valorisation are manifold. They include public and private entities, ranging from the public authorities at the local, regional and national level, the public bodies in charge of the management of natural and cultural assets in the Euganean Hills area (such as the Regional Institute for Venetian Villas and the Euganean Hills Regional Park Authority), the DMO Thermae and Euganean Hills and the LAG Padua, which are public-private consortia, the Diocese of Padua, and private Civil Society Organizations active in the protection and promotion of the cultural and natural heritage of the area.

\section{Management recommendations}

Based on the above analysis, some management recommendations for an improved valorisation of the villa and its long-term conservation in a key of economic sustainability can be provided, with the identification of strategic objectives and the suggestion of an action plan for implementation. The strategic objectives identified include:

1. Conservation;

2. Education and participation;

3. Management;

4. Introduction of new productive activities;

21 3,261,032 total presences in 2017, of which 32,066 in the nearby municipalities of Arquà Petrarca, Baone, Cervarese Santa Croce, Cinto Euganeo, Vo, Lozzo Atestino, Rovolon (OGD, Organizzazione di Gestione della Destinazione Terme e Colli Euganei. Piano di start up, 2018).

22 Regione Veneto, Piano Strategico del Turismo del Veneto, Allegato alla Deliberazione Consiliare n. 19 del 29 gennaio 2019 relativa a: Piano Strategico del Turismo del Veneto (Programma Regionale per il Turismo - legge regionale n. 11/2013, art. 6), 2019.

23 OGD, Organizzazione di Gestione della Destinazione Terme e Colli Euganei. Piano di start up, 2018.

24 Regione Veneto, Piano Strategico del Turismo del Veneto, Allegato alla Deliberazione Consiliare n. 19 del 29 gennaio 2019 relativa a: Piano Strategico del Turismo del Veneto (Programma Regionale per il Turismo - legge regionale n. 11/2013, art. 6), 2019. 


\section{Research; \\ 6. Marketing; \\ 7. Tourism; \\ 8. Funding.}

For each strategic objective, actions were suggested, by indicating the level of priority (low, medium, high) and timeframe (short, medium, long term). As mentioned, among recommendations was the introduction of possible productive activities that could valorise the villa and its assets, which are described in the following section.

\section{Introduction of new productive activities}

The identification of new productive activities into the heritage site of Villa Beatrice should be aligned with the values of the site and its cultural significance, and also be based on a sound analysis of what kind of activities could support the economic sustainability of the site, providing resources for its maintenance. In the case of Villa Beatrice d'Este, the introduction of productive activities is per se very much in line with the values of the site and its historical functions, as the site was the centre of the productive life of the area when it was a monastery and also when it was an active Venetian Villa.

The methodological approach applied in the definition of the productive activities and in the study of their feasibility was developed and tested in the field on other local and European case studies by the Venetian Cluster ${ }^{25}$.

Selection of key sectors of analysis

Based on the values of the site, the wishes of the owner and some recent market analyses on the tourism segment of the area ${ }^{26}$, the field of analysis was restricted to the following key sectors of activities:

1. Hospitality;

2. Slow Tourism services and experiential tourism;

3. Restaurants;

4. Wine bars, tastings, wine shops;

5. Trading of local food and wine products;

6. Yoga and meditative sports;

7. Wellness centres, massages, naturopathy;

8. Team building activities;

9. Creative craftsmanship. 


\section{Territorial analysis}

The analyses targeted the selected sectors to identify the productive activities in the territory of Villa Beatrice carried out at concentric centres from the position of the villa $(1 \mathrm{~km}, 10 \mathrm{~km}$, $30 \mathrm{~km}$ ). The primary sources used for the research were Google and some specific websites on the Euganean Hills area ${ }^{27}$. For activities within $1 \mathrm{~km}$, the analysis went into detail; for activities within a $10 \mathrm{~km}$, only a representative sample of the activities was taken into consideration, and details were examined within the samples. For the area within $30 \mathrm{~km}$, the details of the individual activities were not considered, but their areas of concentration were taken into consideration. In addition to the above, the Venetian Villas in the area of the Thermae e Euganean Hills Tourist Destination were analysed, in order to check what the main services offered are (those villas are compared to Villa Beatrice as type of buildings).

The results of the analysis are summarized hereunder.

The productive activities within $1 \mathrm{~km}$ from the villa are very limited in number, and do not cover all the sectors considered, as shown in Table 2 (the area mainly corresponds to the Mount Gemola, within the Municipalities of Baone and Cinto Euganeo). None of the activities is located within a historic building or Venetian Villa.

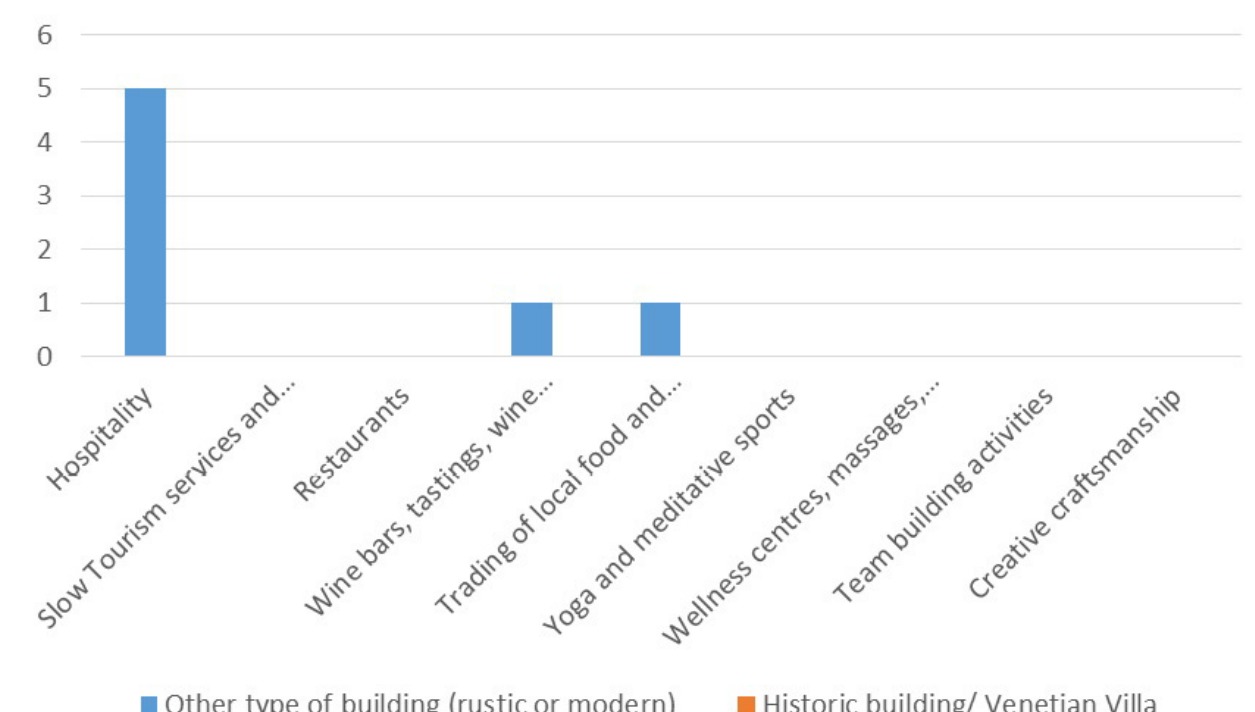

Tab. 2 Productive Activities within $1 \mathrm{~km}$ from Villa Beatrice

27 Such as that of the Wine Route (http://www.stradadelvinocollieuganei.it/) or that of the Euganean Hills Regional Park (http://www.parcocollieuganei.com/) 
The area within a $10 \mathrm{~km}$ radius roughly corresponds to the territory of the Euganean Hills Park and to large part of the Tourist Destination "Thermae and Euganean Hills". As shown in Table 3 , the activities within this area are numerically representative, especially for some sectors, such as hospitality, restaurants, wine bars and wine shops, and the trading of typical food and wine products, confirming the agricultural and touristic vocation of the Euganean area. A small percentage of the surveyed activities is located within historic buildings or Venetian Villas. The activities that were taken into consideration, particularly regarding the most numerically relevant sectors, represent an indicative sample of the actual number of activities, which could not be totally covered by the survey.

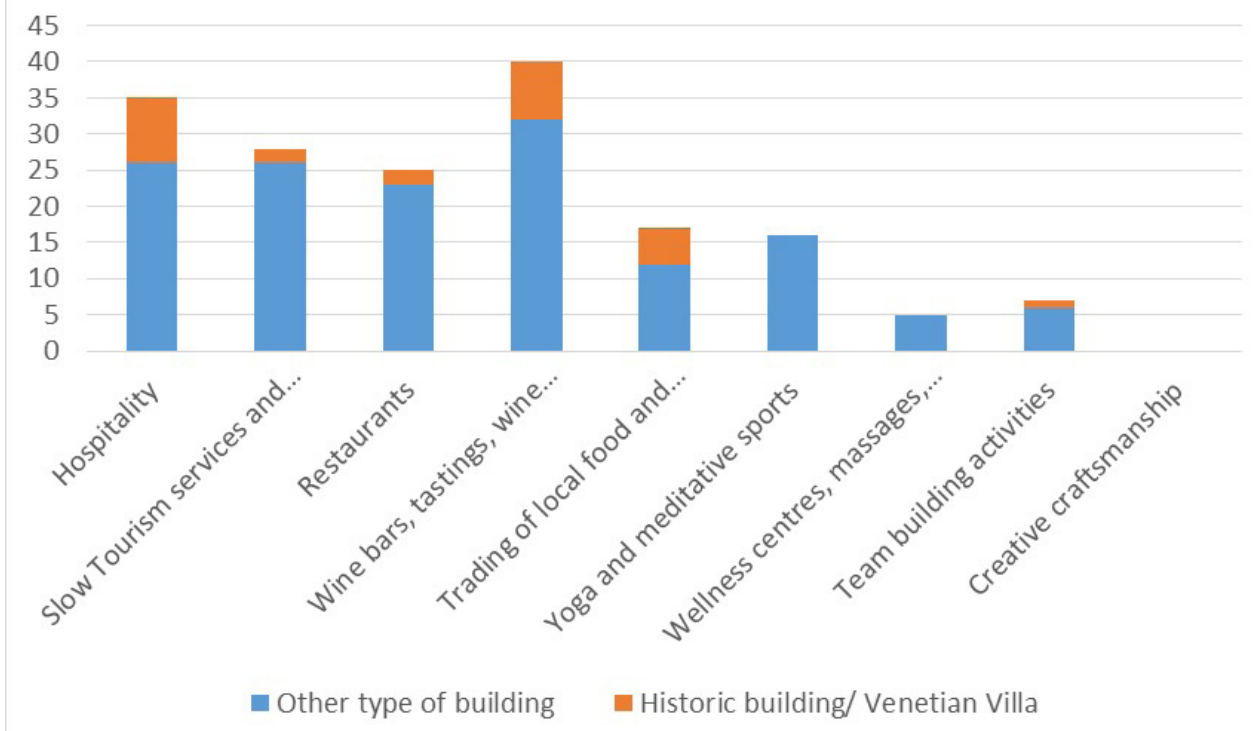

Tab. 3 Productive Activities within $10 \mathrm{~km}$ from Villa Beatrice

For the sector of hospitality, the analysis went to further consider the type of services offered, including extra services, showing that most of the activities offer bedrooms rather than houses or apartments, but that for historic buildings the situation is the opposite. As shown in Table 4 , the analysis also highlighted that there are few campsites and that glamping is almost absent (only in one case, glamping was offered as an experience). Finally, it was noted that only in few cases specific services for bike tourists were offered (and none of them in historic buildings), and that yoga or meditation were not offered if not occasionally. However, within the analysis of the Slow Tourism Services in the area, represented activities include tours by bicycle, horseriding, or walking; food and wine tours; cultural and thematic tours; cooking courses, showing a potential cooperation between the two sectors. 


\begin{tabular}{|l|l|l|l|l|l|}
\hline Context & Bedrooms & $\begin{array}{l}\text { House/ } \\
\text { apartments }\end{array}$ & Camping & Bike services & $\begin{array}{l}\text { Yoga, } \\
\text { meditation }\end{array}$ \\
\hline Rustic & 14 & 6 & 2 (camping) & 4 & - \\
\hline Modern & 5 & - & - & - & - \\
\hline Historic & 2 & 8 & 1 (glamping) & 1 & 2 \\
\hline TOTAL & $\mathbf{2 1}$ & $\mathbf{1 4}$ & $\mathbf{3}$ & $\mathbf{5}$ & $\mathbf{2}$ \\
\hline
\end{tabular}

Tab. 4 Analysis of hospitality activities within $10 \mathrm{~km}$ from Villa Beatrice

Regarding restaurants, the analysis showed a wide and capillary distribution of such activities in the area, with a prevalence of local traditional cuisine with a rustic style and only two cases of restaurants inserted within the context of a Venetian Villa.

Wine bars, tastings and wine shops also showed a wide distribution, given the high presence of wineries and farms in the area. These are mainly farm and agritourism activities, which offer wine tasting services mostly upon reservation. At the level of Venetian Villas or historic buildings, there is a good presence of this type of activities, but, in almost all cases, these are wineries or farms located within historic buildings, and not wine bars.

Regarding yoga and meditative sports, there are several centres and schools mainly concentrated in the area of the Euganean Spas and in urban contexts. Some associations organize sporadic events in the Euganean Hills area.

The analysis of wellness centres took into consideration only the activities located outside the Euganean Spas basin, where all thermal structures offer a wide range of wellness-related services, and showed a very scarce presence of such activities in the Euganean Hills area.

Finally, regarding the sector of creative craftmanship, research showed some typical productions, such as pottery in the Este area, the goldsmith and silverware manufacturing, the leather processing, and the weaving, but specific activities could not be identified.

The area within $30 \mathrm{~km}$ is more varied, including entirely the city of Padua, the area of the Berici Hills up to the southern area of Vicenza, the centres of Cologna Veneta and Montagnana, the area to the south of the Euganean Hills, down to Rovigo, the area south-east of Padua and the area between Padua and Vicenza. The activities in the area are more widely represented, with concentrations in the urban centres. The analysis carried out did not go into detail but could spot attracting poles for the activities in the centres of Padua and further south in Rovigo. The area of the Berici Hills represents a similar but distinct hilly system from that of the Euganean Hills; it is therefore interesting to compare it with the Euganean Hills system.

Finally, the analysis went to consider the activities inserted in the context of Venetian Villas and historic buildings within the Destination "Thermae and Euganean Hills" to verify how many Venetian Villas within $30 \mathrm{~km}$ from Villa Beatrice have developed activities in the identified productive sectors, as shown in Table 5. The analysis showed that the most represented activity is hospitality and that other activities are represented, although in smaller numbers. Most of the villas or historic buildings are located within a $30 \mathrm{~km}$ radius from Villa Beatrice d'Este. 
The case study of Villa Beatrice d'Este: management planning of a multi-layered site [...] 41

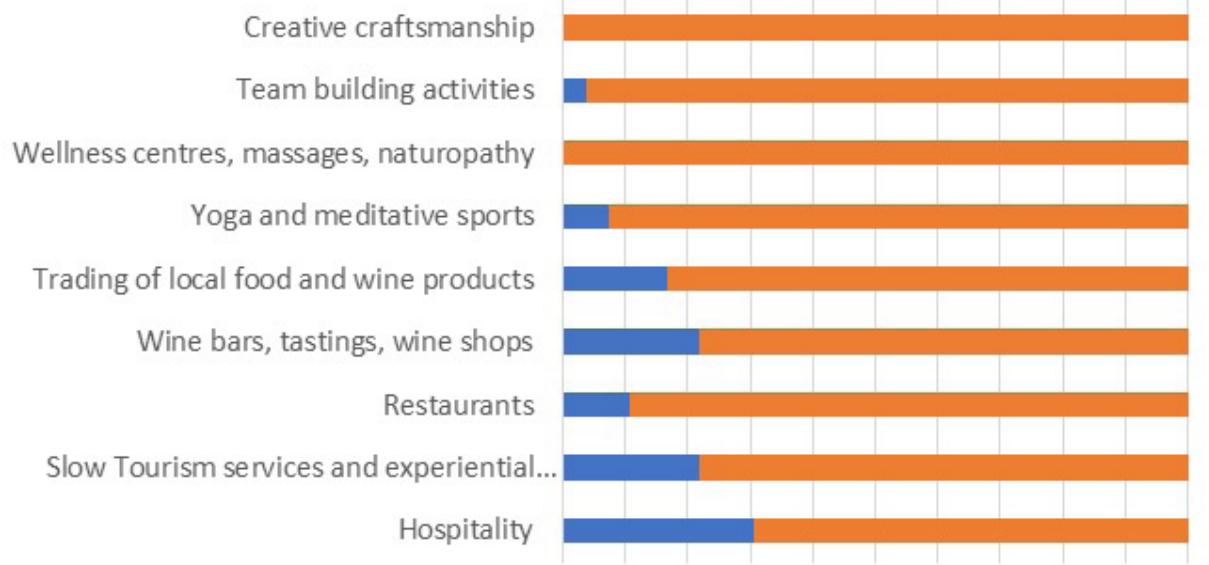

0\% 10\% 20\% 30\% 40\% 50\% 60\% 70\% 80\% 90\%100\%

- Number of activities $\quad$ Total number of villas

Tab. 5 Activities inserted in Venetian Villas and historic buildings in the destination Thermae and Euganean Hills

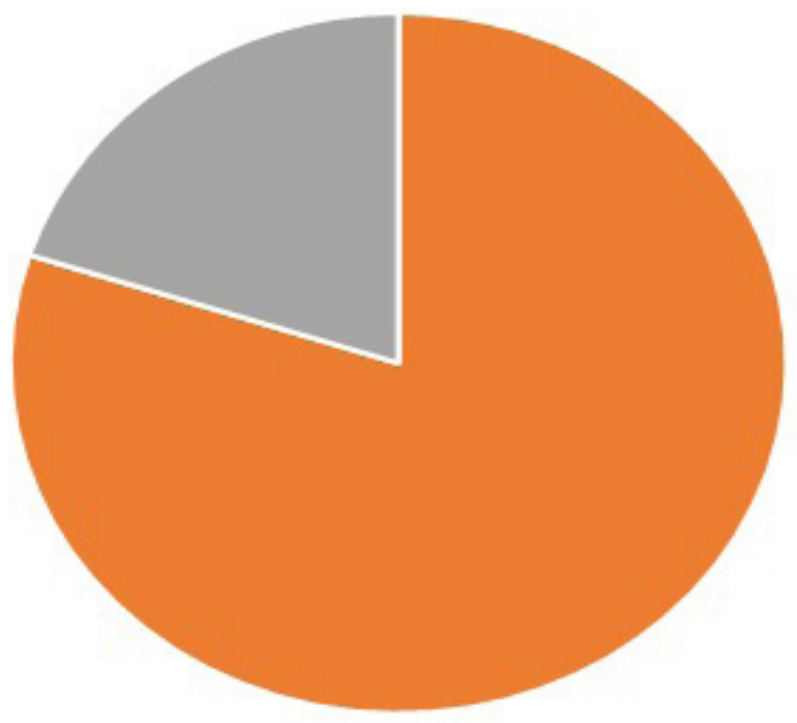

- Within $1 \mathrm{~km}$ - Within $10 \mathrm{~km}$ Within $30 \mathrm{~km}$

Tab. 6 Concentration of Venetian Villas showing productive activities within the three analysed areas 


\section{SWOT Analysis}

Based on the overall analysis, including the diagnosis of the site, the examination of its management and the territorial analysis of productive activities, a SWOT analysis was undertaken to identify potential strengths and opportunities for the management and valorisation of Villa Beatrice in a key of economic sustainability.

\begin{tabular}{|c|c|}
\hline $\begin{array}{l}\text { STRENGHTS } \\
\text { Historical house } \\
\text { Panoramic position at } 360^{\circ} \\
\text { Strong symbolic and spiritual value } \\
\text { Great tranquillity and distance from urban } \\
\text { centres } \\
\text { Medieval archaeological heritage } \\
\text { Natural heritage } \\
\text { Location for events }\end{array}$ & $\begin{array}{l}\text { WEAKNESSES } \\
\text { Difficult connections } \\
\text { Scarce visitor services and facilities } \\
\text { High operating costs } \\
\text { Inaccessible areas }\end{array}$ \\
\hline $\begin{array}{l}\text { OPPORTUNITIES } \\
\text { Connection to slow tourism } \\
\text { Experiential tourism } \\
\text { Inclusion in natural or cultural itineraries } \\
\text { Tangible and intangible medieval heritage to be } \\
\text { valorised } \\
\text { Use of new technologies } \\
\text { Collaboration with stakeholders } \\
\text { Collaboration with local farmers } \\
\text { Possibility to use the spaces that now are } \\
\text { inaccessible } \\
\text { Introduction of a ticket to access the outside } \\
\text { areas } \\
\text { Introduction of activities related to meditation / } \\
\text { meditative sports }\end{array}$ & $\begin{array}{l}\text { THREATS } \\
\text { Force majeure } \\
\text { Variability of the tourism sector } \\
\text { Less flow in the winter months } \\
\text { Competition }\end{array}$ \\
\hline
\end{tabular}

\section{Possible activities and feasibility}

Based on the above, a hypothesis of some productive activities that could be included in the villa was provided, with a preliminary economic feasibility plan, starting from the metric calculation of the villa spaces and based on a cost estimate per square meter for the restoration works, including systems and set-up. Such activities include the possible introduction of a B\&B targeting the slow and experiential tourism market and of a glamping activity in the outside areas; the introduction of yoga and meditative sports services, in connection or independently from the hospitality services; the introduction of a wine bar in cooperation with local wineries and excellences; the provision of team building activities. The suggested activities could enter in synergy with the museum's educational activities, the organization of events such as weddings, meetings, and cultural and eno-gastronomic events. 


\section{Conclusions}

The Management Plan for Villa Beatrice d'Este constitutes as a tool and a basis for the planning and verification of management activities for the villa, including related investments, their typology (productive, social, cultural, etc.) and timing, in order to support future decision making by the owner. To be implemented, the plan needs to be integrated with further considerations by the owner and the site manager entity, in coordination with public and private stakeholders that could be directly involved.

\section{Acknowledgements}

The Management Plan for Villa Beatrice d'Este and this article were elaborated within the framework of the EU project RUINS, funded by the EU Territorial Cooperation Programme Interreg Central Europe. The Province of Padua, site owner, and Butterfly Arc Ltd., current manager of the site, provided support in the collection of data and in the review of the plan. 


\section{Bibliography}

Brogiolo G. P., Este, l'Adige e i Colli Euganei. Storie di paesaggi, Progetti di Archeologia, 2017.

Brogiol, G. P., Paesaggi storici dei Colli Euganei e della pianura padovana tra età romana e medioevo, [in:] Brogiolo, 2017, pp. 9-24.

Cogo B., Beata Beatrice d'Este. 1191-1226. Venerazione e memoria storica. Terra d'Este. Rivista di storia e cultura, Anno XXVII, n. 53, 262 pp., Este: Gabinetto di Lettura Este, 2017.

Monti G., Padova: città e campagne, [in:] Zucchello, 2001 (XV-XIX).

OGD, Organizzazione di Gestione della Destinazione Terme e Colli Euganei. Piano di start up, 2018. Polizzi C. F., Alle origini del monastero di S. Giovanni Battista del Gemola, [in:] Atti e memorie dell'Accademia Patavina di Scienze, Lettere ed Arti, 103, III, 1992, pp. 173-200.

Quarena M., Insediamenti e paesaggi agrari storici di Baone, Calaone e Valle San Giorgio, Tesi di Laurea, Università degli Studi di Padova, 2014.

Quarena M., Castelli, monasteri e paesaggi agrari tra Baone, Calaone e Valle San Giorgio, [in:] Brogiolo, 2017, pp. 89-121.

Regione Veneto, Piano Strategico del Turismo del Veneto, Allegato alla Deliberazione Consiliare n. 19 del 29 gennaio 2019 relativa a: Piano Strategico del Turismo del Veneto (Programma Regionale per il Turismo - legge regionale n. 11/2013, art. 6), 2019.

Rigon A., Pievi, monasteri, eremi, [in:] Selmin, 2005, pp. 141-165.

Selmin F., I Colli Euganei, Sommacampagna: Cierre Edizioni, 2005.

Settia A. A., Castelli Euganei, [in:] Selmin, 2005, pp. 117-139.

Zanovello, P., Le prime tappe della storia: tra Euganei, Veneti e Romani, [in:] Selmin, 2005, pp. 87-115.

Zucchello N., Ville venete: la Provincia di Padova, IRVV, Marsilio, 2001. 